\title{
日本病理剖模螌報に基つく舌酒剖柃症例の統旪的湌时
}

\author{
佐藤方信・岛山節子・佐島三笽子・守田裕辟
}

\section{A statistical survey of the autopsy cases of tongue cancer collected from the Annual of the Pathological Autopsy Cases in Japan}

\author{
Masanobu Satoh - Setsuko Hatakeyama - Mieko Sashima \\ Hiroaki MORITA
}

\begin{abstract}
A statistical survey of tongue cancer, collected from the annuals of pathological autopsy cases in Japan from 1977 to 1981, was done in order to examine the actual facts of tongue cancer.

On the whole, the increase from year to year, of a total number of 404 autopsy cases (male: 293, female: 110, and unknown: 1) of tongue cancer, was revealed. The average age was $65.4 \pm 9.5$ in male and $56.8 \pm 14.9$ years in female. The tongue cancer was found most frequently in the age group of $60 \sim 69$ years, and the lateral borders $(57.7 \%)$ were the most frequently affected sites in the tongue. The lung (44.1\%) was the most common site of metastasis from the tongue, followed by cervical soft tissue $(27.3 \%)$, pharynx $(14.9 \%)$, liver $(14.7$ $\%$ ), larynx $(12.8 \%)$, and thyroid (14.1\%). Concerning the metastasis from the tongue cancer into the lymph node, the cervical lymph nodes $(32.5 \%)$ were most frequently invaded. Multiple primary cancers, affecting both the tongue and other organs, were found in 65 cases (double cancer: 58 cases, triple cancer: 5 casees, quadruplex cancer: 2 cases).
\end{abstract}

Key words: tongue cancer, autopsy cases, statistical survey

緒 言

最近の人口動態統計 ${ }^{1 \sim 5)}$ によれば，わが国において舌 癌で死亡した者はおおむね逐年的に增加していた，著者 ら 3 恃先に日本病理剖検輯報を基に 1972年より1976年ま での 5 年間の舌癌剖検症例について集計した結果を発表 した. 舌癌症例の実態の解明を目的に今回はその後の剖 検症例について集計したので，若千の考察を加えてその 結果を報告する。

\section{岩手医科大学齿学部口腔病理学講座}

（主任：鈴木鍾美教授）

Department of Oral Pathology, School of Dentistry, Iwate Medical University (Chief: prof. Atsumi Suzuki)

受付日：昭和 62 年 9 月 25 日
材 料-方 法

日本病理剖検輯報第 $20 ， 21 ， 22 ， 23 ， 24$ 輯 $~ 211)$ を用い て，1977年から1981年の 5 年間に本邦で行われた剖検症 例の中から舌癌症例を収集し, 種々の観点から検討し た.

成結

\section{1. 碑剖検症例の年度別および年代別症例数}

日本病理剖検輯報によると，この 5 年間に行われた剖 検総数は 163, 215例で, 悪性腫湟剖検総数は94,813例で あった（表 1）。このらちに舌癌剖検症例は 404 例認め られ, 男性が 293 例, 女性が 110 例で, 王倒的に男性が 多かった。 また，舌癌剖検症例は1977年に51例であった が，1981年には 102 例と，この 5 年間に倍增していた。 全剖梌症例中に占める舌癌症例の割合は $0.25 \%$, 全悪性 
表 1 舌癌剖柍定例の年度别推移

\begin{tabular}{|c|c|c|c|c|c|c|c|c|c|c|c|}
\hline \multirow[t]{2}{*}{ 年度 } & 性 & \multicolumn{2}{|c|}{$\begin{array}{c}\text { 剖格定例数 } \\
(\mathrm{A})\end{array}$} & \multicolumn{2}{|c|}{ 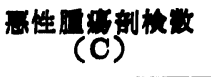 } & \multicolumn{2}{|c|}{$\begin{array}{l}\text { 舌蝠割梌数 } \\
\text { (T) }\end{array}$} & \multicolumn{2}{|c|}{$\begin{array}{c}T / A \times 100 \\
(\%)\end{array}$} & \multicolumn{2}{|c|}{$\begin{array}{c}\mathrm{T} / \mathrm{C} \times 100 \\
(\%)\end{array}$} \\
\hline & 男 & 15,533 & & 9,093 & & 34 & & 0.22 & & 0.37 & \\
\hline \multirow[t]{3}{*}{1977} & 女 & 10,112 & 25,840 & 5,363 & 14,531 & 17 & 51 & 0.17 & 0.20 & 0.32 & 0.35 \\
\hline & $?$ & 195 & & 75 & & 0 & & & & 0 & \\
\hline & 男 & 17,928 & & 10,717 & & 53 & & 0.30 & & 0.49 & \\
\hline \multirow[t]{3}{*}{1978} & 女 & 11,725 & 29,872 & 6,512 & 17,340 & 18 & 71 & 0.15 & 0.24 & 0.28 & 0.41 \\
\hline & $?$ & 219 & & 111 & & 0 & & & & 0 & \\
\hline & 男 & 19,749 & & 12,098 & & 63 & & 0.32 & & 0.52 & \\
\hline \multirow[t]{3}{*}{1979} & 女 & 12,704 & 32,683 & 7,213 & 19,433 & 29 & 92 & 0.23 & 0.28 & 0.40 & 0.47 \\
\hline & $?$ & 236 & & 122 & & 0 & & & & 0 & \\
\hline & 男 & 21,736 & & 13,558 & & 62 & & 0.29 & & 0.46 & \\
\hline \multirow[t]{3}{*}{1980} & 女 & 13,985 & 35,970 & 7,893 & 21,568 & 26 & 88 & 0.19 & 0.24 & 0.33 & 0.41 \\
\hline & $?$ & 249 & & 117 & & 0 & & 0 & & 0 & \\
\hline & 男 & 23,652 & & 13,724 & & 81 & & 0.34 & & 0.59 & \\
\hline \multirow[t]{2}{*}{1981} & 女 & 14,866 & 38,850 & 8,051 & 21,941 & 20 & 102 & 0.13 & 0.26 & 0.25 & 0.46 \\
\hline & $?$ & 332 & & 166 & & 1 & & 0.30 & & 0.60 & \\
\hline \multirow{3}{*}{ 合計 } & 男 & 98,598 & & 59,190 & & 293 & & 0.30 & & 0.50 & \\
\hline & 女 & 63,392 & 163,215 & 35,032 & 94,813 & 110 & 404 & 0.17 & 0.25 & 0.31 & 0.43 \\
\hline & $?$ & 1,231 & & 591 & & 1 & & 0.08 & & 0.17 & \\
\hline
\end{tabular}

表 2 わが国に括ける舌癌症例剖检率の年度別推移

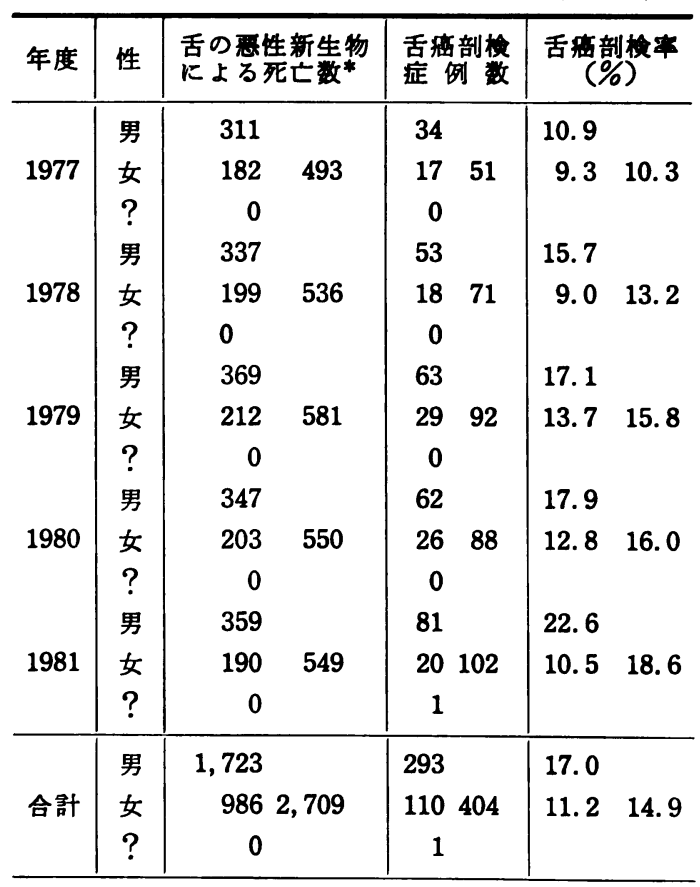

*人口動態統計による

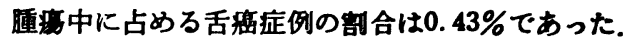

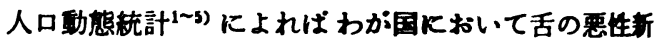
生物によって死亡したるのは，過去 5 年间でおおむね原 年的に增加していた（衰2）．この死亡数を基に舌表症 例の剖検率を算定してみると，1977年には10.3\%であっ たが逐年的に高くなり1981年には18.6\%と高くなってい た.

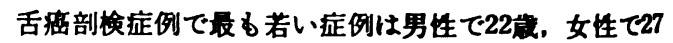

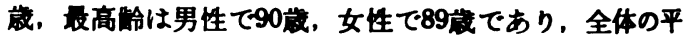

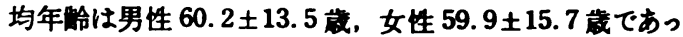
た. 年代別には（表了），60成代 $(28.2 \%)$ が最も多く,

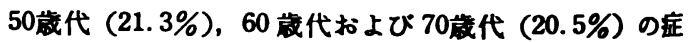
例を合わせると全体の70.0\%となっていた。

\section{2. 舌落の発生部位と相權学的分察}

舌店剖娭症例の発生部位は 300 症例で記されていな かった. 記戴のあった 104 症何について発生部位を見る と（表 4), 舌側很部か 60 例 (57.7\%) と最多く, 舌 根部31例 $(29.8 \%)$ と続き, 舌尖部 6 例 $(5.8 \%)$, 舌下 面 5 例 (4.8\%), 舌背部 2 例 (1.9\%) の順であった。

舌癌発生に左右差はみられなかった。

多重癌症例と発生部位が記毫されていない症例を除い て舌癌の発生部位別の平均年跲をみると, 舌側緑部から 発生した症例は56.7土17.6葴で, 舌根部に発生した症侧

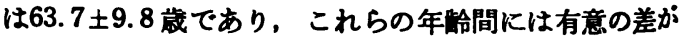
みられた $(\mathrm{p}<0.05)$. また，舌前部，舌下面，舌背部か 
哀 3 舌瘦剖模症例の年代则分布

\begin{tabular}{|c|c|c|c|c|c|c|c|c|c|c|c|c|}
\hline \multirow{2}{*}{ 年度 } & \multirow{2}{*}{ 性 } & \multicolumn{10}{|c|}{ 年 } & \multirow{2}{*}{ 合 旪 } \\
\hline & & $0 \sim 9$ & $10 \sim 19$ & $20 \sim 29$ & $30 \sim 39$ & $40 \sim 49$ & $50 \sim 59$ & $60 \sim 69$ & $70 \sim 79$ & $80 \sim 89$ & $90 \sim 99$ & \\
\hline \multirow{3}{*}{1977} & 男 & 0 & 0 & 0 & 4 & 3 & 4 & 13 & 9 & 1 & 0 & 34 \\
\hline & 女 & 0 & 0 & 0 & 1 & 1 & 8 & 4 & 2 & 1 & 0 & 17 \\
\hline & $?$ & 0 & 0 & 0 & 0 & 0 & 0 & 0 & 0 & 0 & 0 & 0 \\
\hline \multirow{3}{*}{1978} & 男 & 0 & 0 & 1 & 3 & 6 & 9 & 17 & 13 & 3 & 1 & 53 \\
\hline & 女 & 0 & 0 & 0 & 1 & 3 & 3 & 3 & 5 & 3 & 0 & 18 \\
\hline & $?$ & 0 & 0 & 0 & 0 & 0 & 0 & 0 & 0 & 0 & 0 & 0 \\
\hline \multirow{4}{*}{1979} & 男 & 0 & 0 & 3 & 2 & 7 & 18 & 17 & 13 & 3 & 0 & 63 \\
\hline & 女 & 0 & 0 & 1 & 2 & 3 & 5 & 7 & 8 & 3 & 0 & 29 \\
\hline & $?$ & 0 & 0 & 0 & 0 & 0 & 0 & 0 & 0 & 0 & 0 & 0 \\
\hline & 男 & 0 & 0 & 1 & 3 & 10 & 15 & 21 & 9 & 3 & 0 & 62 \\
\hline \multirow[t]{3}{*}{1980} & 女 & 0 & 0 & 0 & 2 & 6 & 7 & 4 & 5 & 2 & 0 & 26 \\
\hline & $?$ & 0 & 0 & 0 & 0 & 0 & 0 & 0 & 0 & 0 & 0 & 0 \\
\hline & 男 & 0 & 0 & 1 & 5 & 17 & 13 & 24 & 16 & 5 & 0 & 81 \\
\hline \multirow[t]{2}{*}{1981} & 女 & 0 & 0 & 1 & 4 & 1 & 4 & 3 & 3 & 3 & 1 & 20 \\
\hline & $?$ & 0 & 0 & 0 & 0 & 0 & 0 & 1 & 0 & 0 & 0 & 1 \\
\hline \multirow{3}{*}{ 計 } & 男 & 0 & 0 & 6 & 17 & 43 & 59 & 92 & 60 & 15 & 1 & 293 \\
\hline & 女 & 0 & 0 & 2 & 10 & 14 & 27 & 21 & 23 & 12 & 1 & 110 \\
\hline & $?$ & 0 & 0 & 0 & 0 & 0 & 0 & 1 & 0 & 0 & 0 & 1 \\
\hline \multicolumn{2}{|c|}{ 合 $(\%)$} & $\left(\begin{array}{l}0 \\
0\end{array}\right)$ & $\left(\begin{array}{l}0 \\
0\end{array}\right)$ & $\begin{array}{c}8 \\
(2.0)\end{array}$ & $\begin{array}{l}27 \\
(6.7)\end{array}$ & $\begin{array}{c}57 \\
(14.1)\end{array}$ & $\begin{array}{c}86 \\
(21.3)\end{array}$ & $\begin{array}{c}114 \\
(28.2)\end{array}$ & $\begin{array}{c}83 \\
(20.5)\end{array}$ & $\begin{array}{l}27 \\
(6.7)\end{array}$ & $\left(\begin{array}{c}2 \\
0.5\end{array}\right)$ & 404 \\
\hline
\end{tabular}

表 4 舌癌剖検症例の発生部位別症例数

\begin{tabular}{|c|c|c|c|c|c|c|c|c|c|c|}
\hline \multirow{2}{*}{ 部 位 } & \multicolumn{3}{|c|}{ 男 } & \multicolumn{3}{|c|}{ 女 } & \multicolumn{3}{|c|}{ 合計 } & \multirow{2}{*}{ 計 (\%) } \\
\hline & 左 & 右 & 不明 & 左 & 右 & 不明 & 左 & 右 & 不明 & \\
\hline 舌 (前) 尖 & 1 & 2 & 2 & 0 & 0 & 1 & 1 & 2 & 3 & $6(5.8)$ \\
\hline 舌 側 転 & 22 & 23 & 0 & 8 & 6 & 1 & 30 & 29 & 1 & $60(57.7)$ \\
\hline 根 & 3 & 5 & 16 & 0 & 3 & 3 & $4^{*}$ & 8 & 19 & $31(29.8)$ \\
\hline 背 & 0 & 0 & 1 & 1 & 0 & 0 & 1 & 0 & 1 & $2(1.9)$ \\
\hline 舌 下 面 & 1 & 2 & 1 & 0 & 1 & 0 & 1 & 3 & 1 & $5(4.8)$ \\
\hline 明 & 14 & 11 & 189 & 5 & 2 & 79 & 19 & 13 & 268 & 300 \\
\hline 合 計 & 41 & 43 & 209 & 14 & 12 & 84 & 56 & 55 & 293 & $404(100)$ \\
\hline
\end{tabular}

*性不明の 1 例を含む

ら発生した症例数は少なかったが平均年龄はそれぞれ $80.3 \pm 4.9$ 歳, $52.0 \pm 11.3$ 歳, 71.0土14.1葴であった。

舌癌の組織像（表 5) は15例で記载されていなかった が，307 例では単に扁平上皮癌（類表皮癌）とのみ記载 されていた。

組織学的分類として記載されていた名称は角化型扁平 上皮癌か24例, 分化型扁平上皮癌が16例，高分化型扁平 上皮癌か23例，中分化型扁平上皮癌か 9 例，低分化型扁
平上癌 8 例，未分化型扁平上皮癌が 1 例，末分化癌が 1 例であった。

組織像別の平均年龄は角化型扁平上皮癌で58.6土13.3 歳, 分化型扁平上皮癌で54.8 12.2 歳, 高分化型扁平上 皮癌で57.8土13.0歳であった。 また，症例数は少なかっ たが，低分化型扁平上皮癌では54.2 211.3 歳と最も若く

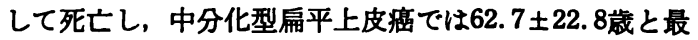
も高龄であった。 なお，扁平上皮癌とのみ記栈されてい 


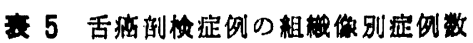

\begin{tabular}{|c|c|c|c|c|}
\hline 粗 & 葪 & 男 & 女 & 合敤 \\
\hline \multicolumn{2}{|c|}{ 扁平上皮癌（狽表皮演） } & 226 & 80 & $307 *$ \\
\hline \multicolumn{2}{|c|}{ 角化型凩平上皮癌 } & 15 & 9 & 24 \\
\hline \multicolumn{2}{|c|}{ 分化型煸平上皮癌 } & 11 & 5 & 16 \\
\hline \multicolumn{2}{|c|}{ 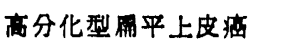 } & 15 & 8 & 23 \\
\hline \multicolumn{2}{|c|}{ 中分化型囘平上皮痤 } & 6 & 3 & 9 \\
\hline \multicolumn{2}{|c|}{ 低分化型网平上皮癌 } & 6 & 2 & 8 \\
\hline \multicolumn{2}{|c|}{ 末分化型䦵平上皮癌 } & 0 & 1 & 1 \\
\hline \multicolumn{2}{|c|}{ 未分化病 } & 1 & 0 & 1 \\
\hline \multicolumn{2}{|c|}{ 不 明 } & 13 & 2 & 15 \\
\hline \multicolumn{2}{|r|}{ 計 } & 293 & 110 & 404 \\
\hline
\end{tabular}

*性不明の 1 例を含む

表 6 舌㾔との多直癌症例の年度别症例数

\begin{tabular}{c|r|r|r|r|r|c}
\hline 年 度 & 1977 & 1978 & 1979 & 1980 & 1981 & 合 計 \\
\hline 男 & 7 & 9 & 7 & 14 & 16 & 53 \\
女 & 0 & 2 & 1 & 5 & 4 & 12 \\
\hline 合 計 & 7 & 11 & 8 & 19 & 20 & 65 \\
\hline
\end{tabular}

た症例では59.6土14.6藏であった。

\section{3. 多重度と重複膜器}

舌癌とは別に他の贜器にも瘦を有するいわゆる多重癌 症例は1977年に 7 例であったか，おおむむね逐年的に增加 し 1981 年には 20 例となり，検索した 5 年間には 65 例 （男性53例，女性12例）が認められた（衰 6)。これらの 多重癌症例の5ち二重癌は58例, 三重癌は 5 例, 四重癌 は 2 例であった（表 7).

多重癌症例の全体の平均年龄は63.8 111.2 葴であり,

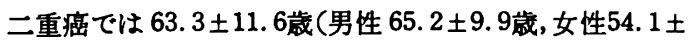
14.4歳）であり，三重癌か６9.8土7.3歳，四重癌が 65.5 土0.7 歳であった。 ちなみに多重瘦を除いた舌癌単独症 例の平均年此合は59.8 14.5 歳（男性59.1土13.9歳，女性 60.4土15.7藏）であった。

組合せ䑏器別（表 7) には二重癌症例では胃, 食道, 肺, 肝などとの重複が多く, 三重癌症例では, 男性で食 道と胃, 女性では性器の瘦と重複していた。 また, 四重 癌症例では口腔と食道のはか胃の早期癌あるいは甲状腺 の潜在癌と重複していた。

\section{4. 舌蕧の転移}

舌癌剖検症例に打いて，転移に関して全く記载のない 症例が22例あり,これらの症例を除いた 378 例について 転移を検討した（表 8 ）.

臓器にのみ転移していた症例は 105 例 (27.5\%) で， リンパ節にのみ転移のみられた症例は23例 $(6.0 \%)$ で,

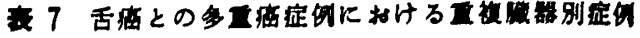
敞

\begin{tabular}{|c|c|c|c|c|}
\hline \multirow{2}{*}{ 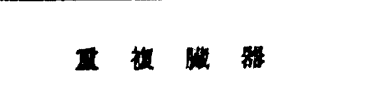 } & \multicolumn{4}{|c|}{ 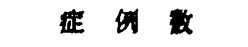 } \\
\hline & S & 女 & 合 & if \\
\hline 二工店应侧数 & 48 & 10 & & \\
\hline 日（含む早期 2 例） & 15 & 1 & & 6 \\
\hline 金 道 & 7 & 1 & & 8 \\
\hline 肺 & 6 & 1 & & 7 \\
\hline 䀒 & 5 & 0 & & 5 \\
\hline リンハ造血 & 3 & $\mathbf{0}$ & & 4 \\
\hline 期立馈 & 3 & 0 & & 3 \\
\hline 甲状滕（合を消在察） & 0 & 2 & & 2 \\
\hline Tr & 2 & 0 & & 2 \\
\hline 蒘 & 2 & 0 & & 2 \\
\hline 上 靨 & 0 & 1 & & 1 \\
\hline 下 硕 & 1 & 0 & & 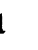 \\
\hline 歏口蓝 & 1 & $\mathbf{0}$ & & 1 \\
\hline 耳下腺 & 0 & 1 & & 1 \\
\hline 舌 & 1 & $\mathbf{0}$ & & 1 \\
\hline 直 䤚 & 1 & $\mathbf{0}$ & & 1 \\
\hline S 状結腭 & 0 & 1 & & 1 \\
\hline 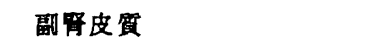 & 1 & $\mathbf{0}$ & & 1 \\
\hline 子宮颗部 & $\mathbf{0}$ & 1 & & 1 \\
\hline 十二指渴平滑筋肉遁 & $\mathbf{0}$ & 1 & & 1 \\
\hline 三重症症例数 & 3 & 2 & & 5 \\
\hline 食道，胃 & 2 & $\mathbf{0}$ & & 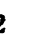 \\
\hline 食道，用（早期） & 1 & $\mathbf{0}$ & & I \\
\hline 外㓌, 子宮项部 & 0 & 1 & & 1 \\
\hline 子宮票部，䏣至 & 0 & 1 & & 1 \\
\hline 四重我症例数 & 2 & 0 & & 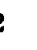 \\
\hline 口腔底，食道，月（早期） & 1 & 0 & & 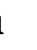 \\
\hline 口膉，食道，甲状腺（潜在） & 1 & 0 & & 1 \\
\hline
\end{tabular}

表 8 舌禹剖湌应䛺において枟移のみられた症保数

\begin{tabular}{|c|c|c|c|c|c|}
\hline \multirow{2}{*}{ 性 } & \multicolumn{2}{|r|}{ 症 } & 体 & \multicolumn{2}{|l|}{ 数 } \\
\hline & 膜 器 & リンィ゚筑 & 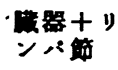 & 坛移なし & 記彭なし \\
\hline 男 & 71 & 21 & 121 & 60 & 20 \\
\hline 女 & 34 & 2 & 50 & 22 & 2 \\
\hline $\begin{array}{l}\text { 合計 } \\
(\%)\end{array}$ & $\begin{array}{c}105 \\
(27.5)\end{array}$ & $\begin{array}{l}23 \\
(6.0)\end{array}$ & $\begin{array}{r}172^{*} \\
(45.0)\end{array}$ & $\begin{array}{c}82 \\
(21.5)\end{array}$ & 22 \\
\hline
\end{tabular}

*性不明の 1 例を含む

贜器とリンハ節に転移がみられた症例は172例 (45.0\%) であった。 なお，82例 (21.5\%) では転移なしと記䉐さ れていた。これらの症例の平均年㱓をみると、䑏器転移 


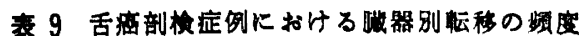

\begin{tabular}{|c|c|c|c|}
\hline \multirow{2}{*}{ 睈 } & \multicolumn{2}{|c|}{ 症 } & 数 \\
\hline & 男 & 女 & it (\%) \\
\hline 新部㳄組滳 & 68 & 36 & $104(27.3)$ \\
\hline 口腔粘䀧 & 17 & 2 & $19(5.0)$ \\
\hline 口蓋 & 13 & 1 & $14(3.7)$ \\
\hline 口腔底 & 12 & 6 & $18(4.7)$ \\
\hline 㮸, 骮膜 & 4 & 3 & $7(1.8)$ \\
\hline 下垂体 & 2 & 0 & $2(0.5)$ \\
\hline 甲状腺 & 31 & 23 & $54(14.2)$ \\
\hline 舌とその周囲 & 6 & 1 & $7(1.8)$ \\
\hline 咽頭 & 37 & 20 & 57 (14.9) \\
\hline 喉頭 & 25 & 24 & $49(12.8)$ \\
\hline 唾液腺 & 3 & 1 & $4(1.0)$ \\
\hline 耳下腺 & 4 & 0 & $4(1.0)$ \\
\hline 顎下腺 & 19 & 7 & $26(6.8)$ \\
\hline 食道 & 15 & 5 & $20(5.2)$ \\
\hline 心 & 27 & 11 & $38(9.9)$ \\
\hline 心重 & 7 & 4 & $11(2.9)$ \\
\hline 気管（支） & 13 & 8 & $21(5.5)$ \\
\hline 眠 & 117 & 51 & $168(44.0)$ \\
\hline 胸膜 & 36 & 11 & $47(12.3)$ \\
\hline 縱隔 & 5 & 6 & $11(2.9)$ \\
\hline 横隔膜 & 14 & 5 & $19(5.0)$ \\
\hline 胃 & 4 & 0 & $4(1.0)$ \\
\hline 渴 & 2 & 2 & $4(1.0)$ \\
\hline 畈 & 43 & 13 & $56(14.7)$ \\
\hline 䏣衰 & 2 & 0 & $2(0.5)$ \\
\hline 脾 & 12 & 4 & $16(4.2)$ \\
\hline 睟 & 8 & 0 & $8(2.1)$ \\
\hline 腹膜 & 6 & 2 & $8(2.1)$ \\
\hline 骨 & 27 & 7 & $34(8.9)$ \\
\hline 副腎 & 24 & 6 & $30(7.9)$ \\
\hline 皮唐 & 23 & 8 & $31(8.1)$ \\
\hline 骨 & 19 & 7 & $26(6.8)$ \\
\hline 頭蓋骨 & 5 & 1 & $6(1.6)$ \\
\hline 下額骨 & 8 & 2 & $10(2.6)$ \\
\hline 脊椎 & 4 & 0 & $4(1.0)$ \\
\hline 颗椎 & 1 & 1 & $2(0.5)$ \\
\hline 胸椎 & 5 & 2 & $7(1.8)$ \\
\hline 腰椎 & 5 & 0 & $5(1.3)$ \\
\hline 胸骨 & 2 & 0 & $2(0.5)$ \\
\hline 助骨 & 6 & 2 & $8(2.1)$ \\
\hline 晹骨 & 1 & 1 & $2(0.5)$ \\
\hline 大酿骨 & 1 & 0 & $1(0.3)$ \\
\hline その他 & 10 & 7 & $17(4.5)$ \\
\hline
\end{tabular}

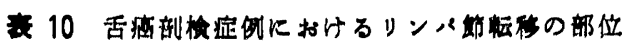
别㖪度

\begin{tabular}{|c|c|c|c|}
\hline \multirow{2}{*}{ 部＼cjkstart位 } & \multicolumn{2}{|c|}{ 症 } & 数 \\
\hline & 男 & 女 & 合此 $(\%)$ \\
\hline 全身 & 1 & 0 & $1(0.3)$ \\
\hline 部 & 93 & 31 & $124(32.5)$ \\
\hline 影下部 & 9 & 4 & $13(3.4)$ \\
\hline 腋菑 & 2 & 1 & $3(0.8)$ \\
\hline 気管分岥部 & 5 & 4 & $9(2.4)$ \\
\hline 肺閒 & 40 & 17 & $57(14.9)$ \\
\hline 䀒阿 & 4 & 2 & $6(1.6)$ \\
\hline 町 & 3 & 0 & $3(0.8)$ \\
\hline 胿阿 & 1 & 0 & $1(0.3)$ \\
\hline 愣間膜 & 1 & 1 & $2(0.5)$ \\
\hline 鎖骨上蕅 & 14 & 6 & $20(5.2)$ \\
\hline 鮴食道 & 2 & 0 & $2(0.5)$ \\
\hline 傍胃 & 3 & 0 & $3(0.8)$ \\
\hline 傍大功脈 & 12 & 4 & $16(4.2)$ \\
\hline 傍気管 & 33 & 15 & $48(12.6)$ \\
\hline 傍膵 & 6 & 0 & $6(1.6)$ \\
\hline 鼠径部 & 1 & 1 & $2(0.5)$ \\
\hline 維隔 & 3 & 2 & $5(1.3)$ \\
\hline その他 & 3 & 2 & $5(1.3)$ \\
\hline
\end{tabular}

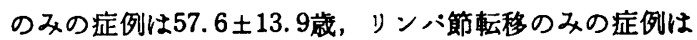
$67.7 \pm 11.5$ 歳, 荗器とリンハ節に転移のみられた症例は $57.8 \pm 14.1$ 歳, 転移のない症例は $64.9 \pm 13.3$ 歳であっ た.

嘷器別の転移の頻度 (表 9) では肺が168例 (44.0\%), 项部軟組織が 104 例 (27.3\%), 咽頭か 57例 (14.9\%), 肝か56例 (14.7\%), 甲状腺か554例 (14.1\%), 啒頭が49 例 $(12.8 \%)$ ，心および心费が 49 例 (12.8\%) で転移が 認められた。

リン八節転移をその部位別（表10）にみると，頙部が 124 例 (32.5\%) で, 肺門か 57例 (14.9\%) で，傍大動 脈が48例 (12.6\%) で転移が認められた。

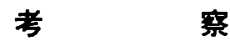

\section{1. 舌症症例と剖検}

舌癌は口貯領域で最も頻繁に認められる悪性腫漡であ る。性別は男性に多く6,12 14)，䄪 85\%は男性である ${ }^{15)}$ と もいわれている，人口動態統計1 5) によればわが国にお いて1977年から1981年までの 5 年間に舌の悪性新生物に より死亡した者はそれぞれ 493，536，581，550，549例 であり，これを性别にみると男性 1,723 例，女性 986 例 で，王倒的に男性症例が多かった．今回の著者らの日本 


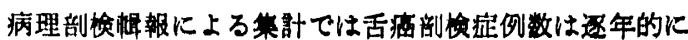

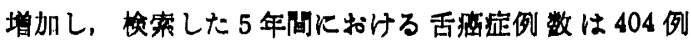
で，舌の烈性新生物による死亡数 ${ }^{1 \sim 3)}$ に対する舌搌淀例 の剖娭率は年々高くなっていた。

1972年か 51976年までの舌瘦剖検症例を日本病理剖娭 輯報から収集して検即した佐藤らの)の集新（以下前報と いら)では，この 5 年間に扰ける舌癌症例は 253 例であっ たが、今回の著者らの娭案では 404 例と著しく增加して いた。 また，総剖検症例数に対する舌癌剖検症例数の割 合は前報的で $0.22 \%$ でったが，今回の成縟では0.25\% と上界していた。

舌癌剖検症例の平均年峆は今回の著者らの検案では男 $60.2 \pm 13.5$ 歳，女 $59.9 \pm 15.7$ 叔であり，前報6)での男

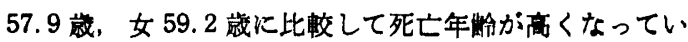
た。この要因は種々あると思われるか，治療法の向上に よることも否定できないと考えた。

舌癌の約 $80 \%$ は50歳代か 570歳代に認められるといわ れるが(15)，今回の剖娭症例の集計では60咸代が28.2\%で 最も多く，50歳か 570藏代の症例を合わせて70.0\%にな

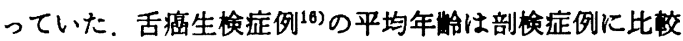
して当然のことながら若く，年代別には 51〜60 慼か最も 多く (25.5\%), ついで 61〜70 歳の $20.4 \% ， 41 〜 50$ 藏の $17.3 \% ， 71$ 80歳が15.3\%と報告されている.

\section{2. 舌菑の発生部位と組織像}

舌癌は舌の側縁部に好発し，舌背中央部，舌尖部およ び舌下面には少ないという ${ }^{15,17)}$ ，佐藤ら ${ }^{18)}$ は生検例の集 計で左右の舌側縁を合わせると $85.8 \%$ になり，舌癌の はとんとはここの部位から発生し，舌根部は $6.4 \%$ ，舌尖 部は $3.6 \%$ ，舌背部および舌下面は $1.8 \%$ であったと報 告している，剖検症例でるる㗍癌の部位別発生頻度は前 報6)の成績を発生部位不明の 22 例を除いて再検討してみ ると, 舌側縁部か $53.2 \%$, 舌根部か33.9\%となり, 今回 の著者らの成䋶は前報6) とほぼ同様の結果であった。

頭頸部癌取扱規約 ${ }^{19)}$ によれば，口腔，舌，喉頭，咽頭， 副鼻腔の扁平上皮癌は組織学的に高分化型, 中分化型, 低 分化型に分類される。これらの部位の癌の $90 \%$ は扁平上 皮癌であるか，組織学的分化度は予後，進展に大きな影

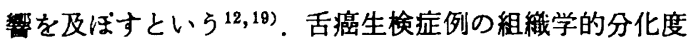
別 (WHO) の症例頻度は分化度 I は58.2\%, 分化度 II は $32.6 \%$ ，分化度吕は $9.2 \%$ ，高分化型が多く，低分 化型が少ないと報告されている(16).著者らは今回日本病 理剖検輯報に記載されていた組織診断名に忠実に集計し てみたが，組織学的分化度別には圧倒的に高分化型が多 かった。たた，単に扁平上皮癌（類表皮㢞）とのみ記覀 されていた症例が 307 例と多く，その大半を占めてい た。

組織学的分化度別にみた舌癌剖検症例の平均年龄は低 分化型と記載されていた症例で $54.2 \pm 11.3$ 歳と最も若 く, 角化型扁平上皮癌で58.6 6 土13.3歳, 高分化型扁平上

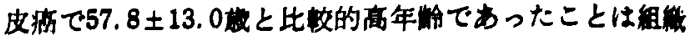
学的分化度と予後を考える上で大变舆味深いことであっ た。

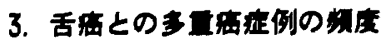

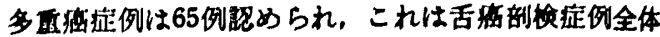

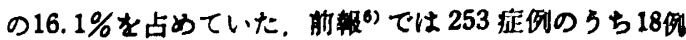

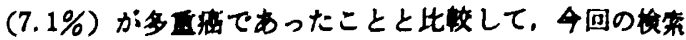
では多血疾の占める割合が蓄しく增加していた。このよ

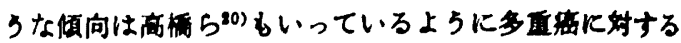

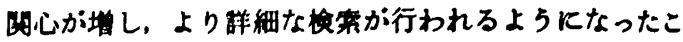
とによると思われた。

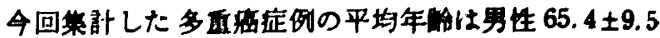

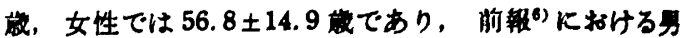

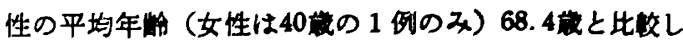
て，男性でやや若くなっていた。

膵器の組み合わせ別には肖，食道，肺，肝などとの面 狼症例が多かったが，これらは前都のです多いとされた 瞙器であった。

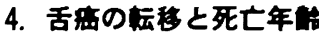

舌癌剖検症例の枟移形成の頑度を灌器とリンハ第下分 けて観察し，前報ののそれと比㜞してみると，今回の㪟

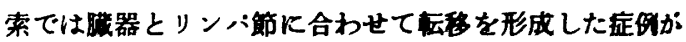
少なくなり，転移なしと記载された症例の害合が高くな っていた。

今回集計した症例の平均年沾はリンハ節にの久枟はの

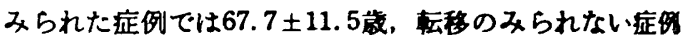
では 64.9土13.3 藏といずれる比校的高かったのに奶し

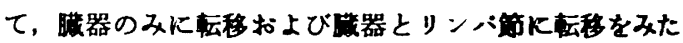
症例ではそれぞれ57.6士13.9藏，57.8土14.1藏と若かっ た。このよらな㑯向は前報のでるみられており，加蛤と 転移形成の成連から興味あることであった。

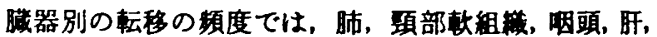
甲状腺，喉頭、胸膜などに枟移を形成した症伍が多かっ

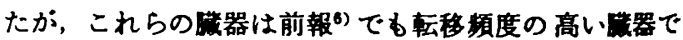
あった。 小守ら ${ }^{21)}$ も舌癌剖検症例の転移では肺 (46.4 \%), 堅 $(17.9 \%)$, 肝 $(14.3 \%)$ 飞転移する症例が多い と報告している。

リンハ節の部位別転移をみると、願部リンバ節は最る 高い転移率を示していたことは前報のと変わりなかった。 傍気管リンバ節転移す前報)と大差がみられなかったが, 肺門リンハ節転移は前報で $7.8 \%$ であったのに対して， 今回の検索では14.9\%と高い値となっていた，また，舌 癌剖検症例のリンハ節では静脈角 $(25.0 \%)$ ，気管支肺 $(21.4 \%)$ ，気管気管支 $(17.9 \%)$, 気管 $(14.3 \%)$ ，腋简 $(10.7 \%)$ ，後腹膜 $(10.7 \%)$ などで枟移の頻度が高いと の報告21) もる。. 
結

\section{铪}

日本病理剖検輯報を基に過去 5 年間（1977～1981）に

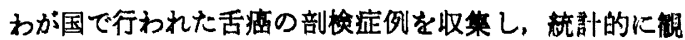
察したところ，次の結論を得た。

1. 症例男性 293 例，女性 110 例，性不明 1 例で， 王倒的に男性が多かった。平均年粭は男性 $60.2 \pm 13.5$ 歳，女性59.9土15.7瓷であった。

2. 過年 5 年間ではおおむね逐年的に舌煰剖検症例は 增加していた。

3. 人口動態兟計から得た舌の黑性新生物による死亡 数に対する舌癌症例の 剖検率は逐年的に高くなってい た。

4. 年代別には60歳代が114例 (28.2\%) で最も多く， 50歳，60歳および70歳代の症例を合わせると全体の70.0 を占めていた。

5. 舌癌の発生部位では舌側縁部 (57.7\%) が最も多か った。

6. 舌癌症例の $78.5 \%$ で㼨器お゙よびリンパ節に転移が みられ，䑏器では肺 (44.1\%), 頸部軟組織 $(27.3 \%)$, 咽頭 $(14.9 \%)$, 肝 $(14.7 \%)$, 喉頭 $(12.8 \%)$ ， 甲状腺 (14.1\%) などが多く、リンハ節では頸部 $(32.5 \%)$, 気 管分岐部 $(14.9 \%)$ ，傍気管 $(12.6 \%)$ などが 目立って いた。

7. 舌癌との多重癌症例は 65 例 (二重癌58例, 三重癌 5 例, 四重癌 2 例) みられ, 年々增加していた。胃癌, 食道癌, 肺癌, 肝癌と重複する症例が多かった。

本研究は圭陵会学術振興会研究助成第31号に上る。 こに付記して謝意を表する。

\section{引用文 献}

1）厚生省大臣官房統計情報部：昭和 52 年人口動態 統計. 下巻, 財団法人厚生統計協会, 東京, 1978.

2）厚生省大臣官房統計情報部：昭和53年人口動態 統計. 下巻, 財団法人厚生統計協会, 東京, 1979.

3）厚生省大臣官房統計情報部：昭和54年人口動態 統計.下巻, 財団法人厚生統計協会, 東京,
1981.

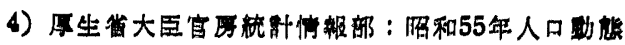

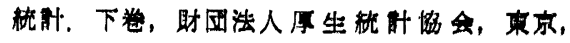
1982.

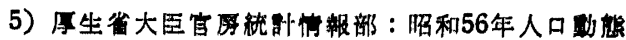

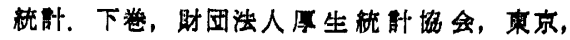
1983.

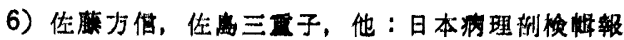

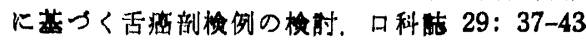
1980.

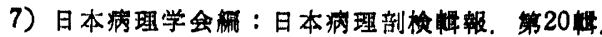

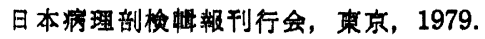

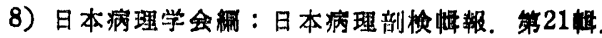
日本病理剖㭘辑報刊行会, 東京, 1980 .

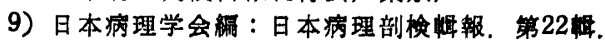
日本病理剖検輯柽刊行会, 東京, 1981.

10）日本病理学会編：日本病理剖㛟輯報。第23輯. 日本病理剖㭘輯報刊行会, 東京, 1982.

11）日本病理学会編：日本病理剖検輯報。第24輯. 日本病理剖㭘輯報刊行会, 東京, 1983 .

12）田代英雄：舌癌。画科汭ャーナル 14：655-662 1981.

13）佐藤方信，皇山節子，他：生检例飞おける舌癌 の病理学的检討. 日只外詰 29: 121-125 1983.

14) Rollo, J., Rosenbom, C.V., et al.: Squamous carcinoma of the base of the tongue: a clinicopathologic study of 81 cases. Cancer 47: 333-342 1981.

15) Kissane, J.M.: Anderson's pathology, vol 2, 8 th ed, Mosby Co, St Louis, 1985, p 1017.

16）佐藤方信，佐島三重子，他：加龄と舌癌に関す 万病理学的检討。口科誌 33: 237-243 1984.

17) 石川梧朗: 口腔病理学 II. 永末書店, 京都, 1982, 624-625頁.

18）佐藤方信, 佐島三重子, 他：生検例より見た舌 病変の臨床病理学的検討. 日口外誌 28: 165316611982.

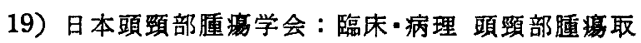
扱規䄪。第 1 版, 金原出版, 東京, 1983，1924 頁.

20）高橋 弘, 岡辺治男, 他: 口腔と他贜器の重䙓 悪性厘瘍について一剖㭘例に上る㭘討一，癌の 臨床 25: 267-272 1979.

21）小守 昭, 森 勝好, 他: 剖検例上りみた顎口 腔領域悪性腫湯の遠隔転移について（第 1 報）. 口科誌 24: 287-297 1975. 